\title{
Trend Pola Asuh Orang Tua dalam Pendampingan Model Pembelajaran Blended Learning pada Masa Pandemi Covid-19
}

\author{
Cindra Suryaputri Anggraeni, ${ }^{1}$ Nur Hidayati, ${ }^{2}$ Hernik Farisia ${ }^{3}$, Khoirulliati ${ }^{4}$ \\ ${ }_{1,2,3}$ UIN Sunan Ampel Surabaya \\ ${ }^{4}$ RA Sunan Ampel Pasuruan
}

DOI : https://doi.org/10.15642/jeced.v2i2.915

\begin{abstract}
This study discusses parenting styles in assisting students' learning with blended learning model in RA. Sunan Ampel, Pasuruan. During the Covid-19 pandemi, RA Sunan Ampel implemented a blended learning model by combining online and offline learning. This study implies descriptive quantitative approach that used questionnaire as the instruments to collect the data. The questionnaire was distributed online to 11 parents of RA students as respondents. The results showed that almost parents have a authoritative parenting style indicated by parents' attitude in engaging children to learning while playing. Meanwhile, such parents also applied permissive parenting characterized by parents' intervention on children's activites and no force for children to learn. Besides that, parents with authoritarian showed that they obey strict rules and punishments when children broke the rules. Above all, such uninvolved parenting implemented during the covid-19 indicated by negligent attitude of parents in engaging students' learning.
\end{abstract}

\section{Article Info}

Article history:

Received: November 11, 2020

Approved: December 28, 2020

Published online: December 31, 2020

Keywords:

blended learning,

parenting style, covid-19 pandemic.

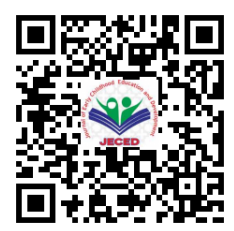

\begin{abstract}
Abstrak
Penelitian ini mengkaji tentang pola asuh orang tua dalam mendampingi pembelajaran peserta didik dengan model blended learning (pembelajaran campuran) di RA. Sunan Ampel Pasuruan. Selama pandemi Covid-19, RA Sunan Ampel menerapkan model pembelajaran blended learning dengan menggabungkan pembelajaran daring (dalam jaringan) dan luring (luar jaringan). Penelitian ini adalah penelitian kuantitatif deskriptif dengan menggunakan angket sebagai instrumen penelitian. Angket tersebut disebarkan secara online kepada 11 orang tua siswa RA Sunan Ampel sebagai responden. Hasil penelitian menggunakan metode kuantitatif deskriptif yang menunjukkan bahwa orang tua memiliki pola asuh demokratis (authoritative), diindikasikan dengan orang tua bersikap bijaksana dalam menghadapi anak yang tidak mau belajar dengan mengajak anak bermain sambil belajar. Pola asuh permisif juga terjadi, ditandai dengan "pembiaran" oleh orang tua terhadap aktivitas dan perilaku anak. Pada pola asuh otoriter, orang tua selalu memberi aturan ketat dan hukuman ketika anak melanggar, misalnya dengan menerapkan sikap dan tegas kepada anak. Dan hanya sebagian kecil orang tua yang menerapkan pola asuh lalai, ditandai dengan sikap lalai orang tua yang membebaskan anak dalam kegiatan:
\end{abstract}

\begin{tabular}{l}
\hline Informasi Artikel \\
\hline Riwayat Artikel \\
Diterima: 11112020 \\
Disetujui: 28122020 \\
Publikasi online: $31 \quad 122020$ \\
\hline
\end{tabular}

\section{Kata kunci:}

blended learniong,

pola asuh orang tua

pandemic Covid-19 


\section{PENDAHULUAN}

Orang tua adalah lingkungan pertama yang berperan besar dalam membangun kompetensi sosial anak. Oleh karena itu, orang tua yang baik harus memiliki perilaku pola asuh yang tepat. Pada dasarnya, pola asuh dapat diartikan sebagai seluruh cara perlakuan orang tua yang diterapkan pada anak (Muslima, 2015, p. 85). Pola asuh merupakan bagian dari proses pengasuhan terhadap anak yang melibatkan interaksi anak dengan orang tua untuk mendorong pertumbuhan dan perkembangan anak. Dengan demikian, pola asuh ialah model pengasuhan anak dengan mendidik anak, merawat anak, mendukung perkembangan fisik, emosi, dan sosial anak.

Ada beberapa tipe pola asuh, diantaranya adalah pola asuh demokratis yakni model pola asuh yang diimplementasikan orang tua dengan mematok standar capaian kematangan anak dengan pola komunikasi yang responsif terhadap segala bentuk pertanyaan dan pendapat anak serta penuh keakraban dan kehangatan. Sedangkan pada pola asuh permisif, orang tua cenderung menerapkan pengasuhan anak dengan selalu dimanja. Pada pola asuh keterikatan, orang tua selalu overprotektif kepada anak. Jenis pola asuh yang lain, yakni pola asuh otoriter adalah pengasuhan orang tua yang selalu memberi aturan ketat kepada anak. Pola asuh lalai dimana orang tua cenderung selalu membebaskan anak, tidak ada peraturan yang tertentu, tidak peduli tentang kegiatan anak dan membiarkan anak sesuka hati anak (Ayun, 2017, p. 106).

Dengan ragam pola asuh tersebut, orang tua harus mampu menerapkan pola asuh yang efektif sesuai dengan kebutuhannya. Pola asuh yang efektif adalah pola asuh yang positif sehingga dapat mendekatkan orang tua dengan anak. Dalam pola asuh positif orang tua harus selalu berbuat positif, menerima anak dengan kondisi adanya, mendukung anak, memfasilitasi kehidupan anak dan bergembira bersama. Pengasuhan yang positif harus menerapkan pola yang benar. Pertama, memahami perkembangan anak, membangun komunikasi yang baik dan menerapkan kedisplinan yang benar. Pentingnya menerapkan pola asuh positif adalah membuat emosi anak stabil.

Pola asuh orang tua sangat dibutuhkan dalam hal pembelajaran anak. Dengan pola asuh yang baik, anak mampu membangun emosi positif untuk mendukung pembelajarannya. Sebagaimana dalam penelitian tentang "Hubungan antara Pola Asuh Orang Tua dengan Motivasi Belajar" tampak bahwa pola asuh yang tepat berkorelasi positif terhadap peningkatan motivasi belajar anak (Kartiyasa Utami et al., 2017, p.21). Motivasi adalah hal yang sangat penting untuk pembelajaran anak karena dengan motivasi anak memiliki minat dan ketertarikan untuk belajar. Untuk menumbuhkan motivasi anak, orang tua dapat menerapkan pola asuh yang tepat, dengan memberikan kasih sayang dan meluangkan waktu untuk anak.

Namun, tidak semua orang tua mampu menerapkan pola asuh yang tepat sehingga berdampak secara psikologis pada diri anak. Dalam penelitian yang dilakukan oleh Dwi Anita dikemukakan bahwa terdapat hubungan antara tingkat pendidikan ibu dengan perkembangan anak usia 48-60 bulan. Semakin tinggi tingkat pendidikan orang tua, capaian perkembangan anak semakin baik (Anita et al., 2013, p. 13). Terutama, di masa pandemi covid-19, pembelajaran pada jenjang PAUD sangat perlu pendampingan dari orang tua mengingat anak-anak bukan pembelajar dewasa. Kondisi ini sebagaimana digambarkan dalam hasil penelitian Fauzi dan Sastra Kusuma bahwa proses pembelajaran dimasa pandemi memerlukan intensitas pendampingan orang tua yang cukup tinggi dalam pembelajaran (Fauzi and Sastra Khusuma 2020, p. 60). Selama masa pandemi covid-19, proses pembelajaran yang biasanya dilaksanakan dengan tatap muka di sekolah bergeser menjadi pembelajaran daring yang lebih banyak melibatkan 
pendampingan orang tua dari rumah. Teknologi, yang pada awalnya sangat minim digunakan untuk pembelajaran, dengan adanya pandemi covid-19 semakin sering digunakan sebagai media pendukung keterlaksanaan pembelajaran online. Untuk mendorong pelaksanaan pembelajaran online yang efektif di masa pandemi covid-19, diperlukan kerjasama siswa, guru, dan orang tua mengingat anak-anak jenjang TK/ RA adalah anak-anak yang berada pada tahap pembelajar awal.

Anak jenjang TK/ RA masih memerlukan intensitas pendampingan yang cukup tinggi sehingga kondisi pembelajaran yang dilaksanakan secara online di rumah masingmasing mengharuskan orang tua melakukan pendampingan. Kondisi ini berdampak pada perilaku orang tua yang sangat meningkat pesat dengan berbagai aktivitas yang beragam. Hasil penelitian Mulyanti (2020) menemukan bahwa dalam keadaan pandemi, perilaku orang tua semakin meningkat dengan menjaga anak, mendampingi anak saat belajar, dan melakukan kegiatan bersama anak. Dengan adanya kebijakan BDR (Belajar Dari Rumah), peran dan tanggung jawab satuan pendidikan banyak melibatkan peran keluarga terutama orang tua. Kondisi ini, pada satu sisi berdampak positif karena keluarga menjadi bagian inti pendidikan melalui penguatan tri pusat pendidikan. Di sisi lain, kondisi ini juga bisa menimbulkan gejala psikomatis seperti kecemasan, stres, emosional, dll (Wardani \& Ayriza, 2020, p. 2).

Kebijakan BDR (Belajar Dari Rumah) telah diimplementasikan di berbagai sekolah di Indonesia, mulai jenjang PAUD sampai Perguruan Tinggi dengan model pembelajaran yang bervariasi bergantung pada kesiapan sekolah dan kondisi zona covid di daerah tersebut. Dengan mempertimbangkan karakteristik anak usia dini sebagai pembelajar awal, kegiatan pembelajaran jarak jauh sangat memerlukan pendampingan orang tua. Salah satu PAUD yang menerapkan pembelajaran jarak jauh adalah RA Sunan Ampel di Pasuruan. Dengan mempertimbangkan kondisi zona wilayah persebaran covid-19 di Pasuruan, sekolah memiliki kebijakan untuk melaksanakan pembelajaran campuran (blended learning). Blended learning adalah kombinasi bentuk pembelajaran berbentuk tatap muka dan virtual. Model pembelajaran ini menggabungkan pembelajaran berbasis internet, multimedia, dan pemanfaatan teknologi. Menurut Congress (2013) "blended learning is some mix of traditional classroom instruction (which in itself varies considerably) and instruction mediated by technology". Dari definisi tersebut dapat dipahami bahwa pembelajaran campuran merupakan perpaduan pembelajaran kelas tradisional dengan pembelajaran kelas modern berbasis internet.

Kondisi pandemi Covid-19 yang semakin luas persebarannya, menjadi salah satu pertimbangan penerapan pembelajaran yang menggunakan berbagai media berbasis internet dan dipadukan dengan pembelajaran yang bersifat luar jaringan (luring). Blended learning sebagai bentuk pembelajaran yang memadukan tatap muka secara langsung dan virtual class yang menerapkan model pembelajaran secara synchronous dan asynchronous membantu siswa mengakses pengetahuan dari berbagai sumber, tidak hanya dari buku tetapi juga dari website atau internet (Anne Ochoa Alpala \& Edith Roberto Flórez, 2011, p. 1). Di RA Sunan Ampel Pasuruan, kebijakan Pembelajaran Jarak Jauh (PJJ) yang diterapkan sekolah bersifat asynchronous, guru dan peserta didik tidak berinteraksi secara bersamaan (Chen, Kaczmarek, \& Ohyama, 2020, p.1). Guru dan peserta didik dapat bertemu dalam waktu yang berbeda sehingga peserta didik dapat mengakses materi ataupun penugasan yang diberikan oleh guru dalam jangka waktu tertentu. Selain itu, dengan mempertimbangkan kondisi Kabupaten Pasuruan yang masih berada pada zona orange, sekolah juga menerapkan pembelajaran secara luring 
dengan menyelenggarakan kegiatan tatap muka pembelajaran secara berkelompok dan bergantian di rumah guru masing-masing dengan tetap menerapkan protokol kesehatan yang ketat.

Blended learning merupakan teknologi secara tersusun untuk memberikan dampak pada kegiatan belajar, membangkitkan minat anak dan menambah sumber belajar. Model pembelajaran campuran (blended learning) memiliki kelebihan dan kekurangan. Kelebihan pada blended learning yaitu pembelajaran dapat dilaksanakan dimana saja, kapan saja dan tidak terbatas waktu, mendorong siswa menjadi pembelajar mandiri, dan fleksibel saat belajar. Kekurangan pada blended learning yaitu pada model pembelajaran ini terkadang minat anak naik turun ketika sedang belajar secara daring dan keterbatasan waktu saat pembelajaran tatap muka. Di samping itu, pada jenjang PAUD, kehadiran orang tua untuk mendampingi pembelajaran anak-anak sangat diperlukan. Faktanya, beberapa penelitian menunjukkan orang tua masih mengalami kendala dalam mendampingi pembelajaran anak di rumah, terutama di masa pandemi, diantaranya adalah orang tua kurang memahami materi yang disampaikan ke anak, orang tua kesulitan membangun mood dan motivasi anak untuk belajar, keterbatasan waktu orang tua untuk mendampingi anak-terutama bagi orang tua yang bekerja, orang tua cenderung emosional saat mendampingi anak belajar, serta berbagai kendala teknis misalnya terkait keterbatasan tools yang dimiliki orang tua dan juga keterbatasan akses jaringan internet (Wardani \& Ayriza, 2020, p.3).

Dengan mempertimbangkan kendala-kendala tersebut dan mengacu pada tahap perkembangan belajar anak, penerapan blended learning bagaimanapun juga perlu melibatkan pendampingan yang intensif dari orang tua. Pendampingan orang tua, dalam hal ini adalah bagian dari pola asuh. Hasil survey awal pada beberapa siswa di RA Sunan Ampel menunjukkan bahwa pada anak-anak dengan kondisi orang tua yang bekerja, pembelajaran mereka sering terhambat terutama ketika anak harus memnuhi portofolio perkembangannya. Ketika anak mengikuti pembelajaran tanpa pendampingan dan pola asuh yang tepat, anak seringkali tidak dapat mengikuti pembelajaran secara maksimal. Dengan demikian, pola asuh orang tua dan lingkungan belajar yang tepat pada anak usia dini sangat berdampak pada kualitas belajar anak. Dengan pola asuh yang tepat, motivasi belajar anak dapat terbangun dan guru dapat menerapkan model blended learning secara efektif.

Oleh karena itu, penelitian ini bertujuan untuk mengidentifikasi trend pola asuh orang tua dalam mendampingi pembelajaran dengan model blended learning sehingga dapat menjadi salah satu rujukan terkait pola asuh yang efektif untuk mendampingi pembelajaran anak di masa dan pasca pandemi covid-19. Ada 4 jenis pola asuh yang menjadi kerangka pikir dalam penelitian ini yakni pola asuh demokratis (authoritative), pola asuh permisif, pola asuh otoriter, dan pola asuh lalai (uninvolved).

\section{METODE}

Penelitian ini adalah penelitian deskriptif kuantitatif dengan tujuan menggali data sedalam-dalamnya tentang model pola asuh orang tua di RA. Sunan Ampel dalam mendampingi siswa selama belajar dari rumah. Penelitian ini menggunakan instrumen survey yang diberikan kepada orang tua siswa TK-A1 RA. Sunan Ampel Pasuruan. Responden penelitian ini berjumlah 11 orang, namun pasca penyebaran kuesioner, hanya 10 orang tua yang mengisi kuesioner tersebut. Penelitian ini dilaksanakan di RA. Sunan Ampel Pasuruan, dilaksanakan selama pandemi Covid-19 dengan melibatkan peneliti secara terus-menerus baik dalam proses pembelajaran daring 
maupun ketika luring melalui kelompok belajar di rumah guru. Peneliti juga ikut serta berkomunikasi dengan orang tua terkait pelaksanaan pembelajaran baik pembelajaran daring maupun luring melalui media Whatsapp' Group. Dengan pengelompokan hasil angket, memudahkan pembaca memahami penerapan pola asuh yang digunakan orang tua dalam mendampingi belajar anak pada masa pandemi Covid-19.

Teknik analisis data yang digunakan dalam penelitian ini adalah analisis persentase, untuk melihat seberapa banyak kecenderungan frekuensi jawaban responden dan fenomena-fenomena di lapangan (Jannah, 2017). Langkah-langkah analisis data dilakukan dengan cara: 1) identifikasi kelengkapan pemerolehan data berdasarkan jawaban yang masuk dari responden, 2) klasifikasi data berdasarkan kriteria yang telah dibuat (Tabel 1. Indikator Pola Asuh Orang Tua), 3) tabulasi data, 4) menghitung frekuensi jawaban responden, 6) melakukan penghitungan dengan teknik presentase, dan 7) memvisualisasikan data dalam bentuk grafik dan atau bagan (Hendrawati, 2016, p. 35). serta melakukan interpretasi data merujuk pada rumusan pertanyaan penelitian. Data pada tahap ini kemudian diperkuat dengan data hasil wawancara untuk memeroleh kedalaman data.

Untuk memeroleh data yang valid dan reliabel, triangulasi sumber data dilakukan dengan cara crosscheck data hasil angket dengan wawancara pada guru kelas dan melakukan observasi pada hasil karya anak yang dikumpulkan melalui whatsapp' group untuk mengetahui capaian pembelajaran anak dengan berbagai pola asuh yang diterapkan orang tua.

\section{HASIL PENELITIAN DAN ANALISIS}

Pandemi Covid-19 menyebabkan adaptasi dan tatanan baru di berbagai sektor kehidupan, termasuk di bidang pendidikan. Pada jenjang PAUD, kegiatan tatap muka langsung ditiadakan untuk mencegah persebaran Covid-19. Untuk merespon hal ini, pemerintah mengeluarkan kebijakan Belajar Dari Rumah (BDR) sebagaimana teruang dalam Surat Edaran (SE) Mendikbud No. 4 tahun 2020 yang diperkuat dengan SE Sesjen No. 15 tahun 2020 tentang pedoman pelaksanaan BDR selama darurat Covid19. Aktivitas BDR dapat bervariasi antar daerah bergantung pada kesiapan sekolah dan kondisi masing-masing daerah.

Pada masa pandemi Covid-19 RA. Sunan Ampel Pasuruan menerapkan model pembelajaran blended learning yang menggunakan dua model pembelajaran dalam satu minggu yakni pembelajaran tatap muka (luring) yang dilaksanakan pada setiap hari Senin dan pembelajaran online secara asynchronous. Kegiatan luring dilaksanakan dalam kelompok-kelompok belajar di rumah guru dan juga di tempat/ fasilitas yang telah ditunjuk sekolah. Dalam pembelajaran ini, guru lebih banyak menggunakan media atau sumber belajar serta lembar kerja berupa gambar atau fingerpainting dan media di sekitar tempat belajar mereka, misalnya tempat cuci tangan sebagai media pembelajaran praktik menerapkan kebersihan. Sedangkan pembelajaran daring (online) secara asynchronous menggunakan platform whatsapp dengan media atau sumber belajar buku tulis kotak untuk tugas menulis, video pembelajaran untuk tutorial, buku aktivitas siswa, dan berbagai sumber penunjang lainnya.

Selama proses model blended ini, seluruh orang tua terlibat mendampingi pembelajaran dengan intensitas dan cara mendampingi yang beragam. Data hasil kuesioner menunjukkan bahwa data pola kecenderungan pola asuh orang tua di RA. 
Sunan Ampel dalam mendampingi pembelajaran anak selama pandemi covid-19 adalah sebagai berikut.

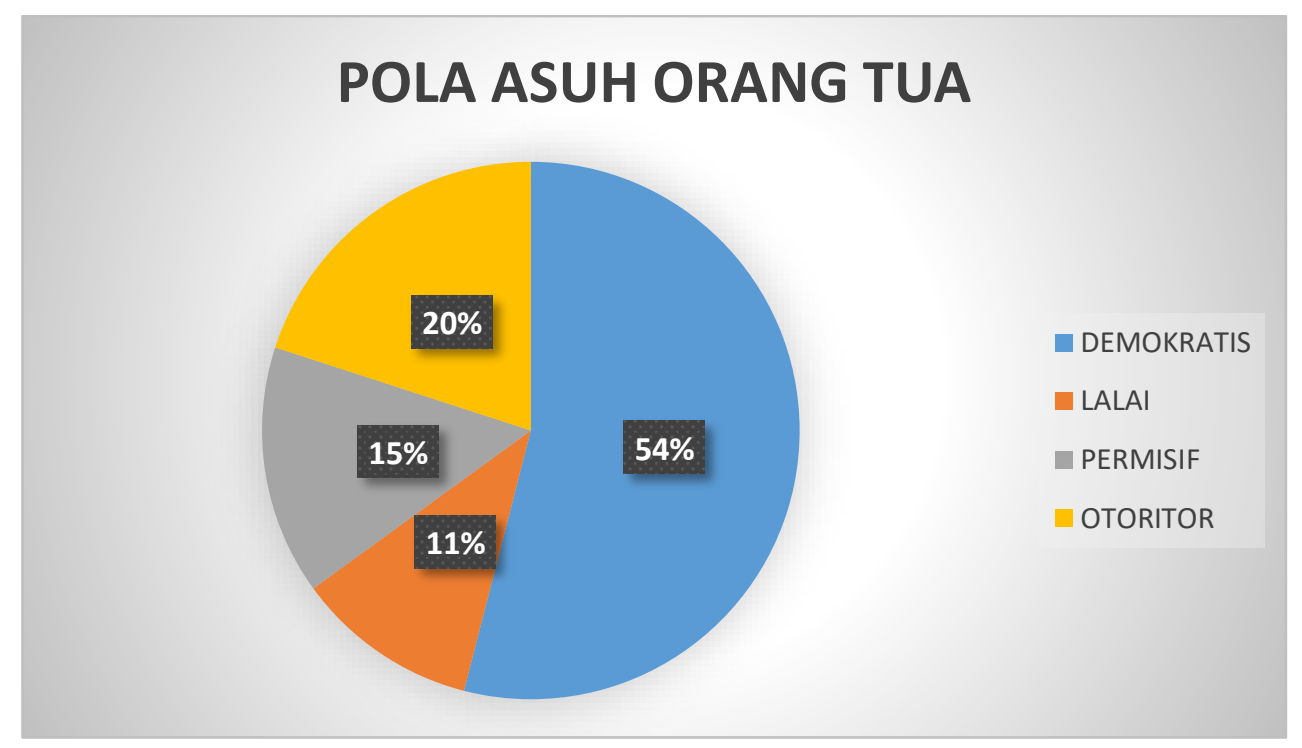

Bagan 1. Prosentase Trend Pola Asuh Orang Tua

Bagan di atas menggambarkan bahwa pola asuh yang banyak diterapkan oleh orang tua adalah pola asuh demokratis, dengan prosentase mencapai 54\%. Adapun sikap dan perilaku orang tua yang menunjukkan pola asuh demokratis adalah orang tua selalu berupaya mengetahui minat dan motivasi anak dalam belajar. Ketika anak tidak mau mengikuti pembelajaran selama daring, orang tua tidak menjustifikasi anak dan atau menyalahkan anak melainkan orang tua mengajak anak berdialog sederhana yang sifatnya dua arah. Kegiatan tersebut dilakukan orang tua sambil mengajak anak bermain. Ketika anak sudah mulai terlibat dalam kegiatan bermainnya, orang tua menunjukkan penugasan yang diberikan oleh guru. Orang tua juga bersikap responsif terhadap anak dan mendukung anak untuk menjadi lebih mandiri.

Sedangkan tipikal pola asuh ke dua yang banyak diterapkan orang tua adalah pola asuh permisif yang menunjukkan orang tua selalu ikut serta dalam kegiatan keseharian untuk mendampingi dan kadangkala menjadi model dalam kegiatan pembelajaran. Orang tua tidak memaksa anak untuk mengikuti model pembelajaran blended learning dan membebaskan anak dalam berbagai kegiatan tetapi masih dalam batasan. Misalnya, dalam salah satu kegiatan wawancara dengan orang tua siswa, ada orang tua yang menyampaikan bahwa mereka cenderung menghadapi anak dengan sabar dan tidak menuntut anak menyelesaikan tugas yang diberikan guru mengingat di masa pandemi anak-anak terlalu banyaknya tugas sehingga motivasi anak belajar menurun. Sedangkan pola asuh otoriter, menempati urutan ke- 3 yakni sejumlah $15 \%$. Pola asuh ini tampak pada adanya tuntutan atau aturan ketat kepada anak dengan memarahi anak ketika tidak mengikuti pembelajaran, bersikap tegas kepada anak, menghukum anak secara fisik ketika anak terlewat batas, memaksa anak untuk mengikuti kemauan orang tua (dalam hal belajar) dan orang tua memberi aturan ketat setiap kegiatan anak. Data ini diperoleh dari hasil wawancara dengan orang tua.

Sedangkan pola asuh lalai (uninvolved) tidak banyak diterapkan orang tua dalam pendampingan belajar anak. Hanya $11 \%$ yang menyatakan bahwa selama masa pandemi orang tua membebaskan seluruh kegiatan anak, membebaskan pilihan anak 
(apakah dia mau belajar atau tidak belajar), dan tidak mempedulikan waktu belajar anak.

Dengan berbagai tipikal pola asuh tersebut, motivasi belajar dan performa siswa baik dalam bentuk kinerja maupun hasil karya sangat variatif. Berdasarkan data hasil wawancara dengan guru kelas di RA Sunan Ampel diperoleh informasi bahwa motivasi siswa dalam belajar tergantung oleh bagaimana orang tua memberi perhatian dan penugasan. Di samping itu, capaian hasil belajar siswa juga variatif dan masih ada beberapa siswa yang belum mencapai kompetensinya secara maksimal.

Adapun kendala-kendala yang dihadapi selama pembelajaran dengan model blended learning adalah 1) Waktu yang dimiliki guru terbatas pada saat pembelajaran tatap muka, orang tua yang menyepelekan tugas anak, orang tua meminta paket data dan guru tidak mengetahui hasil pekerjaan anak yang dikerjakan hasil dari usaha anak secara pribadi. 2) Tidak semua orang tua memiliki latar belakang pendidikan yang cukup untuk mendampingi pembelajaran anak. Terlebih lagi, bagi orang tua yang bekerja penuh waktu, anak-anak sering tertinggal mengikuti kegiatan pembelajaran dan penugasan, 3) Belum adanya dukungan Learning Management System dari sekolah sehingga guru mengalami keterbatasan dalam mengelola pembelajaran. Oleh karena itu, ke depan guru perlu mengasah kompetensi profesionalitasnya terutama terkait kemampuan ICT (Information Communication and Technology) dalam pembelajaran (Rusydiyah, Rusydiyah, Purwati, \& Prabowo, 2020, p. 306).

Dengan mempertimbangkan berbagai kendala tersebut, model pembelajaran yang direkomendasikan orang tua adalah model pembelajaran yang menggabungkan daring dan luring, sebagaimana tampak pada bagan.

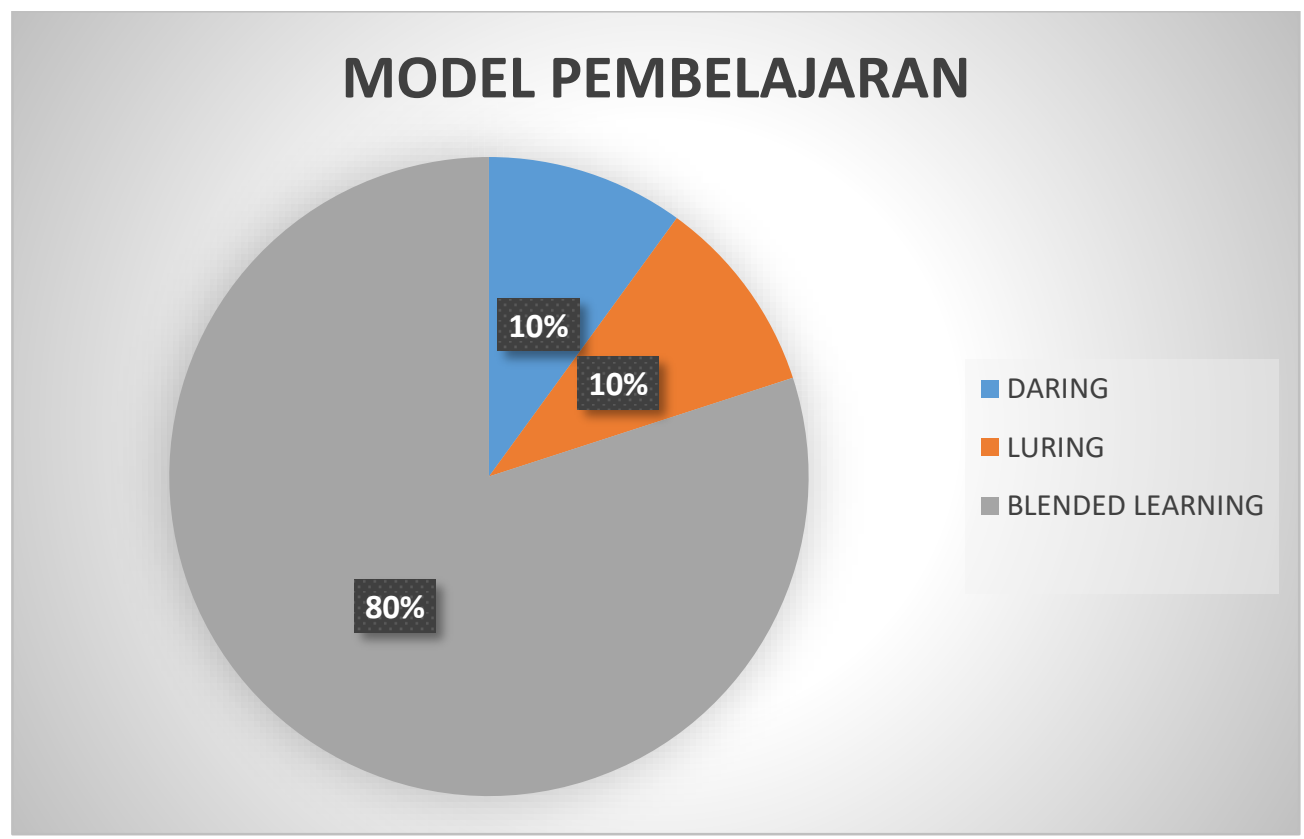

Bagan 2. Model Pembelajaran yang direkomendasikan Orang Tua

Pada bagan tersebut tampak bahwa orang tua siswa cenderung menyukai pola pembelajaran yang masih tetap melibatkan siswa untuk bertatap muka secara langsung dengan guru. Pada grafik hasil pengisian angket oleh orang tua, diperoleh data bahwa sebagian besar orang tua memilih model pembelajaran luring (luar jaringan) sebagai pembelajaran yang efektif dikarenakan dapat memudahkan anak dan guru saling 
merespon dengan baik satu sama lain, anak dapat bermain dengan teman sekelas ketika luring dan pembelajaran luring tidak menyita waktu orang tua yang bekerja. Orang tua yang memilih model pembelajaran daring (dalam jaringan) memberikan argumentasi terkait upaya menjaga kesehatan anak melalui pembatasan interaksi dengan orang banyak selama masa pandemi Covid-19. Sedangkan, orang tua yang memilih model pembelajaran luring dan daring (blended learning) sebagai pembelajaran efektif keduanya, karena sering sekali sekolah mencampur model pembelajaran blended learning ketika adanya kelas tatap muka anak dapat menjadi tanggap dan ketika melaksanakan pembelajaran secara daring, orang tua dapat menjaga kesehatan anak dan melatih anak untuk lebih bertanggung jawab ketika mendapatkan tugas.

\section{PEMBAHASAN}

Keluarga adalah lingkungan pertama dan utama yang turut mendorong perkembangan dan perilaku anak. Oleh karena itu, orang tua perlu membangun hubungan timbal balik yang positif karena pola-pola pengasuhan dan pendidikan yang diterima dan dirasakan anak akan menjadi fondasi dalam pembentukan perilaku anak di masa-masa selanjutnya. Dalam teori empirisme dinyatakan bahwa peran lingkungan sangatlah penting dalam membentuk perilaku anak. Peran lingkungan, termasuk di dalam nya adalah pola asuh dengan demikian perlu menjadi kajian dan perhatian orang tua sehingga anak-anak memiliki fondasi yang kuat dalam pembentukan perilakunya. Namun demikian, dalam menerapkan pengasuhan dan pendidikan, setiap keluarga memiliki pola yang berbeda-beda. Kondisi ini yang menyebabkan pembentukan sikap dan perilaku anak dalam merespon sebuah hal juga berbeda. Pada anak-anak yang tinggal dalam keluarga dengan kecenderungan pola asuh demokratis, mereka cenderung menjadi anak yang respek dan terbuka, bertanggung jawab, dan mandiri (Ayun 2017; Eriani and Amiliya 2020, 106). Pola asuh orang tua yang demokratis juga diyakini sebagai salah satu pola asuh yang membantu anak membangun konsep diri dan motivasi belajarnya (Komsi, Hambali, and Ramli, 2018, p. 56).

Motivasi merupakan keseluruhan daya penggerak dalam diri seseorang yang mendorong tumbuhnya motif keinginan untuk belajar. Hasil penelitian menunjukkan bahwa pola asuh dan lingkungan pembelajaran mampu meningkatkan motivasi belajar anak (Harianti, 2016, p. 21). Dalam penelitian ini, kecenderungan pola asuh yang diterapkan orang tua dalam mendampingi anak-anak mengikuti pembelajaran selama masa pandemi adalah pola asuh demokratis. Beberapa indikator yang menunjukkan orang tua menerapkan pola asuh demokratis misalnya sikap orang tua yang responsif dan tidak menjustifikasi anak jika mereka melakukan kesalahan atau tidak mau belajar. Dengan dukungan pola asuh yang tepat, sikap dan perilaku anak akan berkembang ke arah positif. Secara menyeluruh, beberapa tipikal pola asuh orang tua sebagai rujukan dalam pemetaan kecenderungan pola asuh orang tua di RA Sunan Ampel Pasuruan, merujuk pada tabel berikut (Ayun, 2017).

Tabel 1. Indikator Pola Asuh Orang Tua

\begin{tabular}{ccl}
\hline No & Pola Asuh & \multicolumn{1}{c}{ Deskriptor } \\
\hline 1 & Demokratis & Mengajak anak mengerjakan tugas sambil bermain \\
& & Bersikap responsive \\
& & Mendukung anak lebih mandiri \\
2 & \multirow{2}{*}{ Permisif } & $\begin{array}{l}\text { Memanjakan anak } \\
\text { Ikut serta dalam kegiatan anak }\end{array}$ \\
\hline
\end{tabular}




\begin{tabular}{ll}
\hline & Memiliki kontrol yang rendah terhadap perilaku anak \\
& Tidak memaksa anak dalam pembelajaran \\
& Orang tua memiliki kontrol dan otoritas yang tinggi- \\
& terhadap perilaku anak \\
& Bersikap tegas dalam keseharian anak \\
& Memberikan anak aturan yang sangat ketat \\
& Menghukum anak secara fisik \\
& Memaksa anak melakukan sesuatu yang tidak disukai \\
& Selalu menuntut anak dalam pembelajaran \\
& Membiarkan anak tidak mengerjakan tugas \\
& Membebaskan anak dalam tanggung jawab kehidupan \\
& sehari-hari \\
& Tidak peduli dengan pelajaran anak
\end{tabular}

Berbagai pola asuh sebagaimana digambarkan pada tabel di atas, tentu, akan turut menentukan bagaimana anak-anak membangun nilai-nilai dan sikap dalam kehidupannya. Pola asuh otoriter cenderung menghasilkan karakteristik anak yang penakut, tertutup, gemar menentang, dan menarik diri dari lingkungan sosialnya. Sedangkan pola asuh demokratis, membantu anak menjadi pribadi yang mandiri, lebih percaya diri, mampu mengontrol diri, serta memiliki minat terhadap hal-hal baru. Anakanak yang dibesarkan dengan pola asuh permisif, anak cenderung menjadi egois, tidak suka bekerja keras, kurang disiplin, dan berbagai karakteristik lain (Riati, 2016, p. p.4). Pada pola asuh lalai, anak-anak cenderung terbentuk menjadi pribadi yang sulit membangun hubungan sosial, mudah cemas, sulit mengendalikan emosi, dan memiliki kesulitan dalam hal akademik.

Di antara keempat pola tersebut, pola pengasuhan otoriter merupakan tipe pola asuh yang dampaknya sangat berisiko bagi anak. Hal ini dikarenakan pola asuh otoriter cenderung menetapkan standar yang mutlak harus dituruti anak, bahkan biasanya disertakan dengan ancaman-ancaman. Dengan mempertimbangkan dampak pola asuh orang tua terhadap pembentukan perilaku anak, orang tua harus mampu menerapkan pola asuh yang tepat (Kurniasari, 2016).

Pada masa pandemi covid-19, pendampingan dan pola asuh orang tua sangat diperlukan terutama pada pembelajaran jenjang PAUD. Pola asuh dan pendampingan orang tua ini secara tidak langsung berkontribusi terhadap sikap dan perilaku anak dalam mengikuti pembelajaran. Di RA Sunan Ampel, bentuk perilaku positif anak dalam pembelajaran yang ditemukan di RA Sunan Ampel adalah minat anak untuk mengikuti pembelajaran meskipun dengan sarana prasarana terbatas ketika luring karena pembelajaran tidak dilakukan di sekolah tetapi di rumah guru masing-masing secara berkelompok. Pembelajaran ini diterapkan mengingat Kota Pasuruan masuk kategori zona orange sehingga sekolah belum dibolehkan menyelenggarakan kegiatan pembelajaran di sekolah. Sikap positif siswa juga ditunjukkan ketika mereka menyelesaikan penugasan yang diberikan guru melalui pembelajaran daring asynchronous. Sebagian besar siswa mampu mengumpulkan penugasan tepat waktu dan sesuai dengan tujuan pembelajaran yang telah ditetapkan. Terkait dengan pengembangan life skill dan penguatan karakter, hampir seluruh anak mengumpulkan portofolio mereka ke guru seminggu sekali ketika mereka menyelenggarakan kelas luring, meskipun ada beberapa siswa yang masih terlambat.

Kondisi pembelajaran di RA Sunan Ampel sebagaimana diuraikan di atas menunjukkan bahwa minat belajar siswa masih terbangun selama pelaksanaan 
pembelajaran dengan BDR di masa pandemi ini. Kondisi ini tentu, salah satunya adalah karena adanya dukungan dari orang tua untuk terus mendampingi pembelajaran anakanak dengan pola asuh yang tepat. Merujuk pada hasil penelitian ini, ditemukan bahwa pola asuh yang paling bnayak diterapkan orang tua RA Sunan Ampel adalah pola asuh demokratis, yakni sebesar 54\% orang tua yang menerapkan. Dengan melihat kembali tipikal pola asuh demokratis yang mengedepankan keterbukaan dan pengakuan orang tua terhadap kemampuan anak, tampak bahwa pola asuh demokratis mampu menumbuhkan minat belajar anak. Menurut Dariyo (2011), pola asuh demokratis merupakan gabungan pola asuh permisif dan otoriter yang bertujuan untuk menyeimbangkan pemikiran, sikap, dan tindakan antara orang tua dan anak (Novitasari, Hanafi, Naim, Sultan, \& Tirtayasa, 2019, p. 195).

Ada beberapa faktor yang memengaruhi pola asuh orang tua, diantaranya adalah lingkungan tempat tinggal dan pendidikan orang tua. Anak-anak yang tinggal di kota besar, bisa jadi akan mendapatkan kontrol yang lebih ketat dari orang tuanya termasuk dalam pergaulan sosialnya. Termasuk di masa pandemi ini, dimana semua orang diharapkan tetap tinggal di rumah untuk menghindari kontak sosial dengan orang banyak. Di samping itu, faktor tingkat pendidikan orang tua juga memengaruhi pola asuh yang diterapkan pada anak. Semakin tinggi tingkat pendidikan orang tua, capaian perkembangan anak semakin baik (Anita et al., 2013, p. 13). Hal ini dikarenakan orang tua dengan pendidikan tinggi memiliki kesempatan untuk mengakses berbagai informasi dan pengetahuan sehingga lebih siap untuk menerapkan pola asuh yang tepat. Dengan melihat kembali hasil angket terkait demografi data orang tua siswa, ditemukan bahwa dari $54 \%$ orang tua yang menerapkan pola asuh demokratis dalam mendampingi anakanak mengikuti kegiatan pembelajaran selama pandemi, merupakan orang tua dengan latar belakang pendidikan cukup tinggi.

Namun demikian, meskipun dalam berbagai referensi dan hasil penelitian ditemukan bahwa pola asuh demokratis berdampak positif dalam pembentukan karakter dan perilaku anak, ada kalanya orang tua mengkombinasikan berbagai pola asuh yang lain seperti pola asuh otoriter, pola asuh permisif, dan pola asuh lalai dengan melihat kondisi dan kebutuhan anak.

\section{SIMPULAN DAN SARAN}

Hasil penelitian ini memberikan gambaran tentang pentingnya penguatan peran orang tua dalam proses pembelajaran khususnya bagi anak usia dini. Pola asuh yang berkontribusi positif dalam mendukung pembelajaran anak usia dini di masa pandemi adalah pola asuh demokratis yang diintegrasikan dengan pola asuh permisif dan otoriter dengan memerhatikan konteks dan kebutuhan anak.

Pola asuh yang tepat berkontribusi positif terhadap pembentukan perilaku anak usia dini yang akan menjadi dasar dalam perkembangan perilaku mereka pada masamasa berikutnya. Dalam situasi pembelajaran di masa pandemi dimana pembelajaran yang diterapkan oleh sekolah adalah pembelajaran jarak jauh dengan sistem daring dan luring, perlu sekali dukungan dari orang tua mengingat anak usia dini adalah pembelajar yang masih memerlukan pendampingan.

Selain faktor pola asuh, situasi lingkungan belajar dan pemenuhan sarana belajar juga menjadi faktor penunjang keberhasilan belajar siswa. Dengan demikian, pada penelitian lanjutan, perlu dilakukan kajian lebih komprehensif dengan multivariabel untuk mengidentifikasi berbagai faktor yang mendorong keberhasilan belajar siswa jenjang anak usia dini di masa pandemi covid-19 sehingga dapat dijadikan sebagai 
kerangka acuan untuk pembelajaran lebih lanjut dalam merespon kondisi pasca pandemi covid-19.

\section{AKNOWLEDGMENT}

Penelitian ini didukung oleh Laboratorium Fakultas Tarbiyah dan Keguruan melalui program PLP (Praktik Pengalaman Lapangan) II bekerjasama dengan RA Sunan Ampel Pasuruan

\section{DAFTAR RUJUKAN}

Anita, D., Akademi, A., Estu, K., \& Boyolali, U. (2013). Analisis Tingkat Pendidikan dan Pola Asuh Orang Tua dengan Perkembangan Anak Usia 48-60 Bulan. In Jurnal Ilmiah Kebidanan (Vol. 4).

Anne Ochoa Alpala, C., \& Edith Roberto Flórez, E. (2011). Blended Learning in the Teaching of English as a Foreign Language: An Educational Challenge. In $\mathrm{HOW}$ $\begin{array}{llll}\text { Journal (Vol. 18). Retrieved } & \text { from }\end{array}$ https://www.howjournalcolombia.org/index.php/how/article/view/57

Ayun, Q. (2017). Pola Asuh Orang Tua dan Metode Pengasuhan dalam Membentuk Kepribadian Anak. ThufuLA: Jurnal Inovasi Pendidikan Guru Raudhatul Athfal, 5(1), 102-122. https://doi.org/10.21043/thufula.v5i1.2421

Chen, E., Kaczmarek, K., \& Ohyama, H. (2020). Student perceptions of distance learning strategies during COVID-19. Journal of Dental Education. John Wiley and Sons Inc. https://doi.org/10.1002/jdd.12339

Eriani, E., \& Amiliya, R. (2020). Blended Learning: Kombinasi Belajar Untuk Anak Usia Dini di Tengah Pandemi. MITRA ASH-SHIBYAN: Jurnal Pendidikan Dan Konseling, 3(01), 11-21. https://doi.org/10.46963/mash.v3i01.112

Fauzi, I., \& Sastra Khusuma, I. H. (2020). Teachers' Elementary School in Online Learning of COVID-19 Pandemic Conditions. Jurnal Iqra': Kajian Ilmu Pendidikan, 5(1), 58-70. https://doi.org/10.25217/ji.v5i1.914

Harianti, R. (2016). Pola Asuh Orangtua dan Lingkungan Pembelajaran Terhadap Motivasi Belajar Siswa. Curricula, 2(2), 20-30. https://doi.org/10.22216/jcc.v2i2.983

Hendrawati, H. (2016). Analisis Potensi Tenaga Kerja Lokal di Kawasan Bandara Internasional Jawa Barat (BIJB) di Kecamatan Kertajati Kabupaten Majalengka. Retrieved from http://repository.upi.edu

Jannah, M. M. (2017). Identification Parenting Methods in Kindergarten ABA Jogokaryan Yogyakarta. NASPA Journal.

Kartiyasa Utami, N., Utaminingsih, D., FKIP Universitas Lampung, M., Soemantri Brojonegoro No, J., Lampung, B., \& FKIP Universitas Lampung, D. (2017). Hubungan Antara Pola Asuh Orang Tua Dengan Motivasi Belajar The Corelation Between Parenting Pattern With Learning Motivation.

Komsi, D. N., Hambali, I., \& Ramli, M. (2018). Kontribusi pola asuh orang tua demokratis, kontrol diri, konsep diri terhadap motivasi belajar siswa. Psychology, Evaluation, and Technology in Educational Research, 1(1), 55. https://doi.org/10.33292/petier.v1i1.21

Kurniasari, N. D. (2016). Pola Pembelajaran dan Pengasuhan Pendidikan Anak Usia Dini di PAUD Madura. Jurnal Komunikasi, 10(1), 113. https://doi.org/10.21107/ilkom.v10i1.1844

Muslima. (2015). 86| Gender Equality: Internasional Journal of Child and Gender 
Studies. In Gender Equality: International Journal of Child and Gender Studies (Vol. 1). https://doi.org/10.22373/EQUALITY.V1I1.781

Novitasari, P. P., Hanafi, S., Naim, M., Sultan, U., \& Tirtayasa, A. (2019). Pola Asuh Orang Tua Tunggal dalam Menunjang Perkembangan Kecerdasan Emosional pada Anak Usia Dini di Kelurahan Unyur, Kecamatan Serang, Kota Serang, Provinsi Banten. Jurnal Eksistensi Pendidikan Luar Sekolah (E-Plus), 4(2). Retrieved from https://jurnal.untirta.ac.id/index.php/E-Plus/article/view/7314

Riati, I. K. (2016). Pengaruh Pola Asuh Orang Tua Terhadap Karakter Anak Usia Dini (Vol. 4).

Rusydiyah, E., Rusydiyah, E. F., Purwati, E., \& Prabowo, A. (2020). How To Use Digital Literacy As A Learning Resource For Teacher Candidates In Indonesia. Jurnal Cakrawala Pendidikan, 39(2), 305-318. https://doi.org/10.21831/cp.v39i2.30551

Wardani, A., \& Ayriza, Y. (2020). Analisis Kendala Orang Tua dalam Mendampingi Anak Belajar di Rumah Pada Masa Pandemi Covid-19. Jurnal Obsesi : Jurnal Pendidikan Anak Usia Dini, 5(1), 772. https://doi.org/10.31004/obsesi.v5i1.705

\section{AUTHOR}

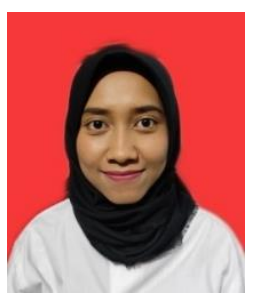

Cindra Suryaputri Anggraeni, lahir di Sidoarjo tanggal 26 April 1998, pendidikan tingkat sekolah dasar di Sdn Pagerwojo Sidoarjo, pendidikan sekolah menengah pertama MtsN Sidoarjo, pendidikan sekolah menengah atas SMK Negri Buduran-Sidoarjo, pendidikan perguruan tinggi Universitas Islam Negeri Sunan Ampel Surabaya.

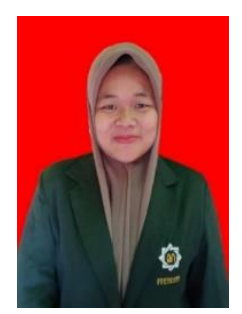

Nur Hidayati, lahir di Sidoarjo tanggal 31 Oktober 1998. Pendidikan tingkat Sekolah Dasar di MI. Tarbiyatus Syarifah Pekarungan-Sukodono, Pendidikan Sekolah Menengah Pertama SMP PGRI 9 Sidoarjo, Pendidikan Sekolah Menengan Atas SMAN 2 Sidoarjo, Pendidikan Perguruan Tinggi Universitas Islam Negeri Sunan Ampel Surabaya

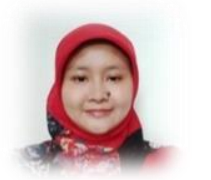

Hernik Farisia, M.Pd.I, lahir di Banyuwangi tanggal 08 Agustus 1983. Saat ini sedang menempuh Program Studi Doktoral Jurusan Pendidikan Dasar di UM Malang dan telah menyelesaikan jenjang Magister pada Prodi PGMI, UIN Sunan Ampel Surabaya pada tahun 2010.

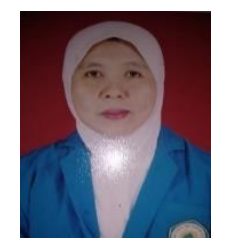

Khoirulliati. S.Pd. lahir di Rejoso-Pasuruan tanggal 24 Agusutus 1973, menempuh pendidikan terakhir S1 Pendidikan Anak Usia Dini STIT ALHIKMAH MOJOKERTO, jabatan guru RA. Sunan Ampel ArjosariRejoso-Pasuruan mulai dari tahun 1998 sampai dengan sekarang. 